\title{
Evolution of paradigms in aeronautical occurrences' investigations
}

\author{
La evolución de paradigmas en las investigaciones de ocurrencias aeronáuticas
}

A evolução de paradigmas nas investigações de ocorrências aeronáuticas

\author{
Ten Cel Av Adalberto Santos Prado \\ Fourth Regional Service for Aeronautic \\ Accident Investigation and Prevention - SERIPA IV \\ São Paulo/SP - Brazil \\ adalbertosprado@gmail.com \\ Cel Av R1 Flavio Neri Hadmann Jasper, Doctor \\ Aeronautic Economy and Finance Secretariat - SEFA \\ Brasília/DF - Brazil \\ fnhjasper@gmail.com
}

\begin{abstract}
With the advance of aeronautical sciences, new theories on air accident investigation were necessary to explain and promote the prevention of these occurrences. Theories that attempt to explain processes involved in aeronautical accidents have suffered evolutions, according to the different realities and aviation development in different times; however, there was no total rupture. Heinrich (1931) published the single cause theory, stating the existence of one unsafe action, next to the accident, which should have been hindered to avoid the damage occurrence. This thought was represented by the domino model and was very important to the appearance of subsequent theories. Reason (1997) developed the theory of multiple causes, represented by the Swiss cheese model. According to that theory, in organizations, there are latent conditions which act on the defense of vulnerabilities and, when aligned with and associated to an active failure, cause the accident. As a result of the evolution of paradigms in aeronautical occurrences' investigations, today, organizational aspects are considered in investigation process and programs for prevention of aeronautical accidents, as well as the identification of hazards or threatens. This concept grounds risk management, keeping it within an acceptable level compatible with the development of air activities. Those evolutions of paradigms in flight safety processes were analyzed in the light of the Kuhn's (1991) scientific revolutions theory, by means of descriptive research of two types: the bibliographic, with consultation to theoretical sources like scientific papers, books, dictionaries and periodicals, and the documentary.
\end{abstract}

Keywords: Investigation. Safety. Paradigm. Accident.

Received / Recibido / Recebido $08 / 19 / 14$
Accepted / Aceptado / Aceito $04 / 11 / 15$ 


\section{RESUMEN}

Con el avance de las ciencias aeronáuticas, se tornaron necesarias nuevas teorías sobre investigación de accidentes aéreos para explicar y promover la prevención de esas ocurrencias. Las teorías que buscan explicar los procesos involucrados en los accidentes aeronáuticos sufrieron evoluciones, de acuerdo con las diferentes realidades y desarrollos de la aviación en las diversas épocas, sin embargo no hubo una ruptura total. Heinrich (1931) publicó la teoría de la causa única, con la existencia de una acción insegura, cercana al accidente, que debería ser impedida para que no hubiese un daño. Ese pensamiento fue representado por el modelo del dominó y fue muy importante en el surgimiento de las teorías siguientes. Reason (1997) desarrolló la teoría de las causas múltiples, representada por el modelo del Queso Suizo. Según esa teoría, en las organizaciones, hay condiciones latentes que actúan en las vulnerabilidades de las defensas y, cuando son alineadas y asociadas a una falla activa, provocan el accidente. Como resultado de la evolución de paradigmas en las investigaciones de ocurrencias aeronáuticas, actualmente, los aspectos organizativos son considerados en los procesos de investigación y en los programas de prevención de accidentes aeronáuticos, así como en la identificación de peligros o amenazas. Este concepto fundamenta la administración del riesgo, manteniendo dentro de un nivel aceptable y compatible con el desarrollo de la actividad aérea. Esas evoluciones de paradigmas en los procesos de seguridad de vuelo fueron analizadas a la luz de la teoría de las revoluciones científicas de Kuhn (1991), a través de investigación descriptiva de dos tipos: la bibliográfica, consultando fuentes teóricas, como artículos científicos, libros, diccionarios y periódicos, y la documental.

\section{Palabras clave: Investigación. Seguridad. Paradigma. Accidente. RESUMO}

Com o avanço das ciências aeronáuticas, novas teorias sobre investigação de acidentes aéreos tornaram-se necessárias para explicar e promover a prevenção destas ocorrências. As teorias que procuram explicar os processos envolvidos nos acidentes aeronáuticos sofreram evoluções, de acordo com as diferentes realidades e desenvolvimento da aviação nas diversas épocas, porém não houve uma ruptura total. Heinrich (1931) publicou a teoria da causa única, com a existência de uma ação insegura, próxima ao acidente, que deveria ser impedida para que não ocorresse o dano. Esse pensamento foi representado pelo modelo do dominó e foi muito importante no surgimento das teorias seguintes. Reason (1997) desenvolveu a teoria das causas múltiplas, representada pelo modelo do queijo suíço. Segundo essa teoria, nas organizações, há condições latentes que atuam nas vulnerabilidades das defesas e, quando alinhadas e associadas a uma falha ativa, provocam o acidente. Como resultado da evolução de paradigmas nas investigações de ocorrências aeronáuticas, atualmente, os aspectos organizacionais são considerados nos processos de investigação e nos programas de prevenção de acidentes aeronáuticos, assim como na identificação de perigos ou ameaças. Esse conceito fundamenta o gerenciamento do risco, mantendo-o dentro de um nível aceitável e compatível com o desenvolvimento da atividade aérea. Essas evoluções de paradigmas nos processos de segurança de voo foram analisadas à luz da teoria das revoluções científicas de Kuhn (1991), através de pesquisa descritiva de dois tipos: a bibliográfica, consultando-se fontes teóricas, como artigos científicos, livros, dicionários e periódicos, e a documental.

Palavras-chave: Investigação. Segurança. Paradigma. Acidente.

\section{INTRODUCTION}

The first aeronautical accident which resulted in the first investigation of aeronautical accident in the history occurred on September 17, 1908, in the city of Fort Myer, Virginia. The airship involved was being piloted by Orville Wright, one of the Wright brothers, and the passenger, Lieutenant Thomas Selfridge, was the first fatal victim of world aviation (EBER, 1982).

Since this tragic event, air activities have been developed and improved in order to avoid material and human losses. Under the perspective of losses prevention, there are several theories which have tried to explain the occurrence of aeronautical accidents. Starting from new approaches, other preventive methods were developed, once the investigation of occurrences is an important reactive tool to flight safety.
Thus, this work is intended to analyze the changes in investigation processes of aeronautical accidents, considering the theoretical approach proposed by Kuhn (1991) to explain the structures of scientific revolutions.

\section{INVESTIGATIONS OF AERONAUTICAL ACCIDENTS IN BRAZIL}

Initially, in the development of aeronautical activities in Brazil, military aviation prevailed. Consequently, investigations of occurrences, military or not, were made by the Brazilian Army, by means of Military Police Inquiry (IPM), and by the Brazilian Navy, via Aeronautical Accident Inquiry (IAA). The main purpose of those investigations was the responsibility for the occurrence. 
In 1941, the Aeronautics Ministry was created, with the Aeronautics General Inspection as responsible for investigations of aeronautical accidents. The Aeronautical Accident Inquiry and the Military Police Inquiry were replaced by the Summary Technical Inquiry (ITS), with the objective of providing more agility to investigations of aeronautical accidents.

The Service for Investigation of Aeronautical Accidents was established on April 5, 1948, by Decree $n^{\circ}$ 24.749, which established the investigations purpose. In this document, the adoption of preventive or repressive measures to avoid new accidents was provided. So, it was up to the Air Zone Commander and to Units Commanders to impose disciplinary sanctions to those responsible for accidents, reinforcing the punitive character of flight safety at that time. In case of evidence of crime or contravention, an IPM should be initiated, concomitantly or after the aeronautical investigation, as described in the Decree. It was organized, in the Third Division of the Inspection of the Air Force General Staff, a section responsible for matters related to aeronautical accidents, with the incumbency to inspect the Decree fulfillment, to guide the Accident Responsible persons in units and the Accident Commissions about the most appropriate methods of investigation, to suggest preventive measures, to receive and analyze accident processes, besides to make statistics calculations and disclose results.

On October 11, 1965, with Decree $n^{\circ} 57.055$, there was a significant change in the model of aeronautical accidents' investigation in Brazil, because aeronautical accidents started to be analyzed considering human, material and operational factors. The ITS and the Summary Report were replaced by the Report of Aeronautical Accident Investigation (RELIAA) and by the Final Report (RELFIN).

Under Decree $n^{\circ}$ 69.565, of November 19, 1971, the abbreviation SIPAER started to mean System of Investigation and Prevention of Aeronautical Accidents and Center for Investigation and Prevention of Aeronautical Accidents (CENIPA) as a central body of this System. From then on, the term Inquiry would no longer be used in investigations of aeronautical occurrences and the purpose of investigations became exclusively preventive, according to international norms.

In 1973, to separate investigation procedures of aeronautical accidents intended to prevent similar occurrences from of investigation procedures intended to identify responsibilities, Brazil suggested to the International Civil Aviation Organization (ICAO) the substitution of the term inquiry for investigation. In 1974, ICAO accepted and adopted the Brazilian proposal.
Today, NSCA 3-6 (military aircraft) and NSCA 3-13 (civil aircraft) have established protocols for investigation of aeronautical occurrences under Brazilian responsibility. In the case of civil aviation, CENIPA forwards to ICAO the Final Report and the Accident/Incident Data Reporting (ADREP), when the occurrence meets severity and maximum weight at take-off internationally established. This information helps composing ICAO data bank used to manage flight safety worldwide.

Law $\mathrm{N}^{\circ}$ 12.970, of May 8, 2014, disposes on investigations carried out by SIPAER and establishes that the only purpose of these investigations is the prevention of other accidents and incidents. It also defines that Safety Recommendations can be issued at any phase of the investigation and that will be considered even hypotheses to identify contributing factors. This aspect distinguishes SIPAER investigation, with preventive purpose, from Police investigation, with other purposes. Hypotheses and other factors investigated by SIPAER do not necessarily obey criteria required to assign civil or criminal responsibility, because they defend life, a priority right in Brazilian legal order. Professional secrecy and protection to information, provided in the mentioned law, contribute to the efficacy of the investigation conducted by SIPAER, since they encourage the voluntary delivery of important information to prevent new accidents.

\section{EVOLUTIONS OF PARADIGMS IN GLOBAL FLIGHT SAFETY}

\author{
According to Kuhn, \\ paradigms are scientific realizations universally \\ acknowledged which, during some time, provide problems \\ and model solutions to a community of practitioners of a \\ science. (KUHN, 1991, p.13, our translation).
}

Under this perspective, evolution of paradigms related to flight safety foundations did not occur only in the purpose of investigations of aeronautical occurences in Brazil. The aviation, in other countries as well, used to adopt the a fly-crash-fly attitude, which is, flights were performed until some accident occurred; so, the airship would be recovered, the occurrence would be investigated, and corrective action would be adopted then the air activity could be retaken. Accidents' causes were assigned to meteorological conditions, to mechanical failures and, generally, to human error, mainly the pilot's. In this last case, the old philosophy would recommend, basically, to encourage other pilots not to commit the same mistake, while the prevention cycle was being considered as concluded (STOLZER; HALFORD; GOGLIA, 2008). 
Nowadays, flight safety is systematically studied. Concepts like Safety Management Systems (SMS) - already used in other sectors like chemical, food and electric industries - were incorporated to ICAO documents. This tool was recommended to all countries signatory of Chicago Convention by means of document (DOC) n 9859, Safety Management Manual, 1st edition, 2006.

According to ICAO (2013), the history of flight safety can be split into three ages:

Technical age: until the end of the 1960s, aviation appeared as a form of transportation and safety themes were associated to technical and technological problems. Starting from the 1950s, technological progress brought reduction in accidents statistics and the flight safety incorporated questions of fulfillment of rules and supervision issues.

Human factors age: in the beginning of the 1970s until the middle of the 1990s, the frequency of aeronautical accidents had already been reduced, due to technological advances, and aviation became the safest means of transport. Thus, a new focus was sought to keep on reducing aeronautical accidents' statistics. Studies on manmachine interaction and human performance in tasks related to aeronautical activities appeared. However, there was no understanding the human behavior could be influenced by different environmental and organizational conditions, affecting their performance.

Organizational age: starting from the second half of the 1990s, flight safety started to be viewed in a systemic way, considering not only human and technological factors, but organizational as well. From then on, impacts of organizational culture and safety policies on risk control were considered, keeping them at an acceptable level. The methodology for data collection and analysis were also reformulated. Formerly, flight safety studies were based on information collected after negative events, basically severe accidents and incidents, essentially reactive measures. By means of a proactive perspective, safety levels indicators started to be constantly monitored in order to identify hazards or threatens and manage risks, to prevent accidents.

Evolutions of paradigms in flight safety can be analyzed under Kuhn's (1991, p.22) theory perspective: "the development of most sciences has been characterized by continuous competition among different conceptions with distinct nature", as described by ICAO (2013), in other words:

Initially, aeronautical accidents were investigated considering technological factors. From a certain moment, the technological approach was no longer sufficient to reduce statistics of aeronautical accidents and human factors started to constitute a new paradigm in the prevention of aeronautical accidents. Later, it was verified that the research focused on the man, without considering organizational and operational factors that affect his behavior, would not be enough to explain aeronautical accidents and to promote flight safety, which gave rise to new approach on the theme.

It is worth mentioning that during the transitions between the historic ages of aviation there was no rupture, but an evolution of paradigms, since the new perspectives would not have been possible without the former experiences. For example, though flight safety today seeks to act proactively, the reactive practices of aeronautical accidents' investigation were not abandoned.

Regardless of how organizational factors were considered in preventive measures, technological aspects and human factors were not dismissed. As regards the theories on aeronautical accident occurrence, an evolution of paradigm in the model also occurred.

Heinrich (1931) has created the single cause theory or the domino theory. It is a linear model, cause-effect type, in which the investigation would be focused on factors more closely connected to accidents, as represented in Figure 1. Heinrich (1931) did not consider productive, for example, to investigate higher administration levels. He defended that it would be possible to avoid the accident, even after the drop of the first domino piece, if one of the pieces in the sequence was removed, that is, unsafe acts.

Figure 1 - Single cause theory.

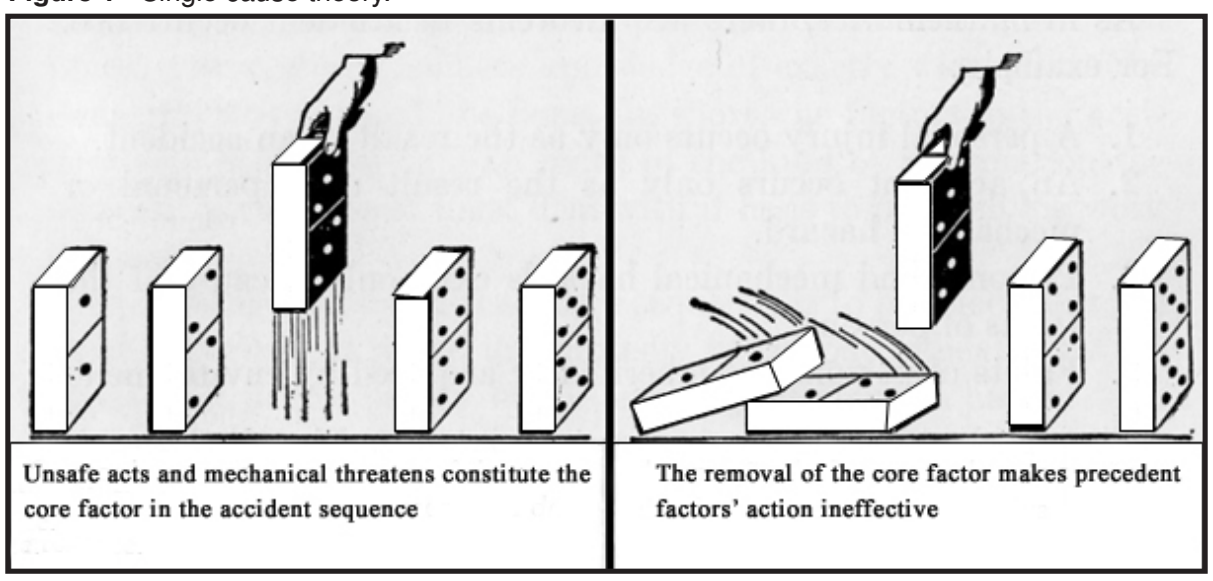

Reference: Adapted from Heinrich (1931). 
Reason (1997) model, known as "Swiss Cheese" or multiple cause theory, does not defend one single cause as triggering a sequence of events that would lead to the accident, but linear combinations of latent conditions and active failures that constitute several chains, and, after surpassing safety barriers due to the alignment of vulnerabilities, culminate in the accident, as shown in Figure 2. Reason (1997) remarks the influence of the organization in accidents' occurrence. Therefore, investigations should look for latent conditions that may induce to situations propitious to active failures. Thus, the most effective prevention should identify hazards or threatens and manage risks (REASON, 1997).

Reason (1997), though concerned with investigating organizational aspects and the influence of higher administration levels as contributing factors, kept the active failure defended by Heinrich (1931) in the description of accident occurrence. Thereby, there was no total rupture, but an evolution of paradigm that, somehow, is supported by previous paradigms.

Today, there is a tendency to represent an accident in a systemic way. According to Hollnagel (2004), Rasmussen's (1997) model adaptation gave rise to this new perspective, in which the accident would no longer be analyzed under a linear optic, but through multiple factors in a disorganized and simultaneous action.

Hollnagel (2004) defends that a system varies according to a stochastic model, because the manifestation of these variations is random and indeterminate, however the sum of variations, acting simultaneously, can potentiate the probability of accidents.

In Hollnagel's (2004) view, accident investigations should not look for a cause-effect relation to create defenses or barriers, because variations in internal interactions make inefficient this approach for accident prevention. So, it would be more appropriate to investigate the whole system, its interactions and variations, so that prevention would be based on variability follow-up and capacity to adapt to pressures, considering factors that can act in the system in a stochastic and resonant way. Resilience becomes the main safety criterion due to the need to adapt to circumstances, the flexibility of complex systems and indispensable capacity to return to balance after instability.

The systemic model, though not linear, did not represent a total rupture with previous representations, because the different factors influencing safety are still relevant during the investigations.

\section{CONCLUSION}

Investigations of aeronautical accidents are conducted according to theories that attempt to explain these occurrences. Thus, the evolution of paradigms on subjects related to flight safety, such as human error, contributing factors and causes, also promotes the evolution in investigative methods.

In the history of flight safety, when a theoretical set no longer satisfactorily explains accidents and does not reduce statistics, new theories arise and propose a better adequacy to reality.

Thus, the evolution of aeronautical accidents can be explained in the light of the theory formulated by Kuhn (1991), since aeronautical sciences also suffer paradigmatic evolutions, without total rupture in the conceptual structure.

Figure 2 - Theory of multiple causes.

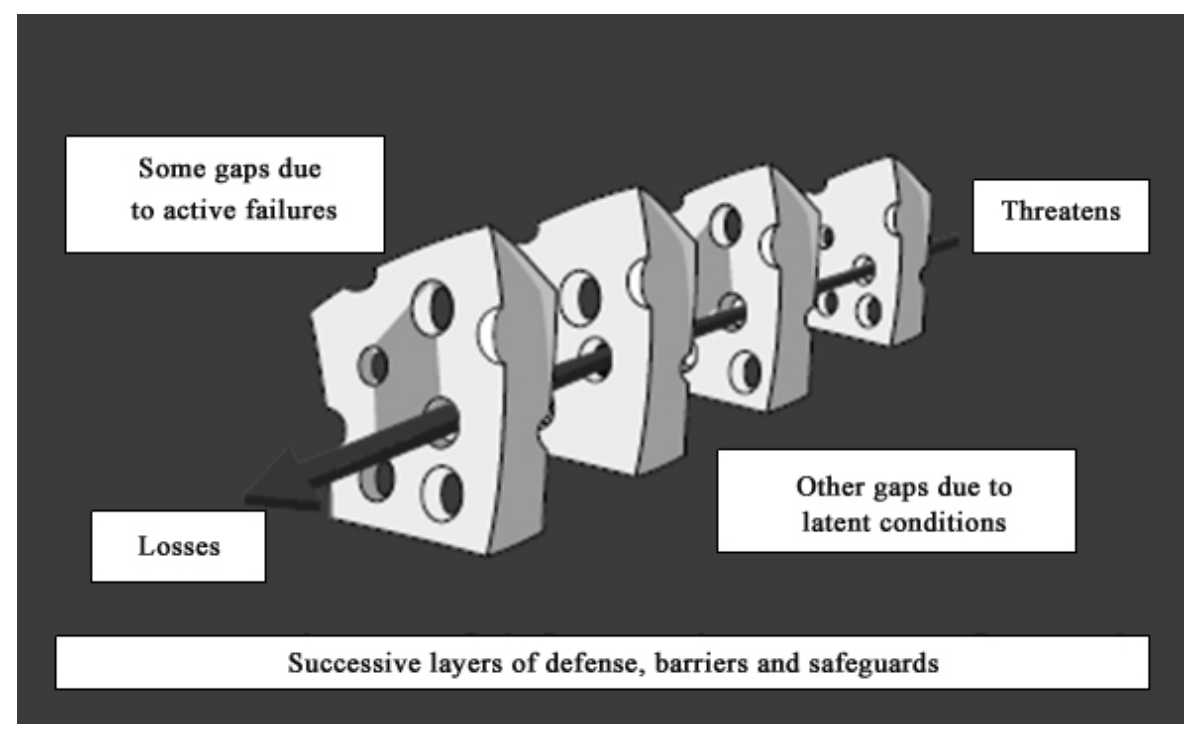

Reference: Adapted from Reason (1997). 


\section{REFERENCES}

BRASIL. Comando da Aeronáutica. Gabinete do Comando da Aeronáutica. Portaria no 2.230/GC3, de 23 de dezembro de 2013. Aprova a reedição da NSCA 3-6, que dispõe sobre a Investigação de Ocorrências Aeronáuticas com Aeronaves Militares (NSCA 3-6). Boletim do Comando da Aeronáutica, Brasília, DF, n. 248, f. 12148, 30 dez. 2013.

. Comando da Aeronáutica. Gabinete do Comando da Aeronáutica. Portaria no 166/GC3, de 12 de fevereiro de 2014. Aprova a reedição da NSCA 3-13, que dispõe sobre os Protocolos de Investigação de Ocorrências Aeronáuticas da Aviação Civil conduzida pelo Estado Brasileiro (NSCA 3-13) Boletim do Comando da Aeronáutica, Brasília, DF, n. 034, f. 1285, 18 fev. 2014.

Decreto nำ 24.749, de 05 de abril de 1948. Aprova o Regulamento para o Serviço de Investigação de Acidentes Aeronáuticos. Diário Oficial da União. Brasília, DF, 07 abr. 1948. Seção 1, p. 5523.

Decreto $\mathrm{n}^{\circ} \mathbf{5 7 0 5 5}$, de 11 de novembro de 1965. Aprova o Regulamento para o Serviço de Investigação e Prevenção de Acidentes Aeronáuticos. Diário Oficial da União. Brasília, DF, 19 out. 1965. Seção 1, p. 10636.

Lei $\mathrm{n}^{\circ}$ 12.970, de 8 de maio de 2014. Dispõe sobre as investigações do Sistema de Investigação e Prevenção de Acidentes Aeronáuticos - SIPAER e o acesso aos destroços de aeronave. Diário Oficial da União. Brasília, DF, 09 maio 2014. p. 1.

EBER, D. H. F. F. Sciences, v. 22, n. 4, p. 15-19, 1982.

HEINRICH, H. W. Industrial accident

prevention: a scientific approach. New York:

McGraw-Hill, 1931.

HOLLNAGEL, E. Barrier analysis and accident prevention. Aldershot, UK: Ashgatee, 2004.

INTERNATIONAL CIVIL AVIATION

ORGANIZATION. Doc 9859: Safety Management Manual (SMM). 3. ed. Montreal, 2013.

INTERNATIONAL CIVIL AVIATION ORGANIZATION. Annex 19: Safety Management. Montreal, 2013.

KUHN, T. S. A estrutura das revoluções científicas. São Paulo: Perspectiva, 1991.

REASON, J. Managing the risks of organizational accidents. Burlington:

Ashgate, 1997.

STOLZER, A. J.; HALFORD, C. D.; GOGLIA, J. J. Safety management systems in aviation. Burlington: Ashgate, 2008. 